\section{Correspondence}

http://doi.org/10.11646/zootaxa.4196.3.7

http://zoobank.org/urn:lsid:zoobank.org:pub:139CFA74-53A2-43B9-9208-E8E9D84C59C3

\title{
Niltavinae, a new taxon of Old World flycatchers (Aves: Muscicapidae)
}

\author{
GEORGE SANGSTER $^{1,2,7}$, PER ALSTRÖM ${ }^{3,4,5}$, EMMA FORSMARK $^{6} \&$ URBAN OLSSON $^{6}$ \\ ${ }^{l}$ Department of Bioinformatics and Genetics, Swedish Museum of Natural History, P.O. Box 50007, SE-104 05 Stockholm, Sweden. \\ E-mail: g.sangster@planet.nl \\ ${ }^{2}$ Naturalis Biodiversity Center, Vondellaan 55, Postbus 9517, 2300 RA Leiden, The Netherlands \\ ${ }^{3}$ Department of Animal Ecology, Evolutionary Biology Centre, Uppsala University, Norbyvägen 18 D, SE-752 36 Uppsala, Sweden \\ ${ }^{4}$ Swedish Species Information Centre, Swedish University of Agricultural Sciences, Box 7007, SE-750 07 Uppsala, Sweden \\ ${ }_{5}^{5}$ Key Laboratory of Zoological Systematics and Evolution, Institute of Zoology, Chinese Academy of Sciences, Beijing 100101, China \\ ${ }^{6}$ Department of Biological and Environmental Sciences, University of Göteborg, Box 463, SE-413 90 Gothenburg, Sweden \\ ${ }^{7}$ Corresponding author
}

The relationships among Old World chats and flycatchers (Muscicapidae) have recently been clarified in two independent molecular phylogenetic studies (Sangster et al. 2010, Zuccon \& Ericson 2010). Both studies recovered a well-supported clade of predominantly blue flycatchers of the genera Niltava, Cyornis, Eumyias and Cyanoptila, some species traditionally included in the genus Rhinomyias and one species traditionally included in Ficedula (F. monileger). The family-group name Niltavinae Sangster, Alström, Forsmark \& Olsson, 2010, was introduced for this clade (Sangster et al. 2010). Unfortunately, our description of the new taxon Niltavinae did not include a diagnosis (sensu ICZN article 13.1.1) and thus inadvertently made this name unavailable for nomenclatural purposes (Zuccon 2011). The supplementary data associated with our original paper included evidence by which the taxon Niltavinae can be diagnosed: a 1 base pair (bp) deletion in the ornithine decarboxylase gene, as shown in Figure S1 in the online version (doi:10.1016/j.ympev.2010.07.008), but this was not mentioned in the printed version of our paper. Given that Niltavinae Sangster, Alström, Forsmark \& Olsson, 2010 represents a nomen nudum, and the clade for which this name was intended thus remains unnamed, we here provide the following description:

\section{Niltavinae new subfamily}

Type genus: Niltava Hodgson, 1837.

Diagnosis. The taxon Niltavinae is diagnosed as monophyletic on the basis of a molecular phylogeny (Sangster et al. 2010). Niltavinae differs from all other Muscicapidae (sensu Sangster et al. 2010) by an unambiguous synapomorphic deletion of $1 \mathrm{bp}$ (Sangster et al. 2010: Figure S1), corresponding to nucleotide position 64 in intron 7 of the nuclear ornithine decarboxylase gene of Gallus gallus bankiva Temminck (GenBank accession number EF552724) and position 61 in intron 7 of the nuclear ornithine decarboxylase gene of Taeniopygia guttata (Vieillot) (GenBank accession number FJ408650).

Most members of Niltavinae have blue upperparts, either in both sexes [most species of Eumyias, some races of Cyornis tickelliae Blyth, C. rufigastra (Raffles), C. turcosus Brüggeman] or in males only [all Niltava, most species of Cyornis, both species of Cyanoptila Blyth]. Therefore, blue upperpart colouration may be a synapomorphy of the clade. Blue colouration is not present (presumably lost) in two species of Anthipes [A. monileger (Hodgson), A. solitaris (Statius Muller)], one species of Eumyias [E. additus (Hartert)] and at least five species of Cyornis [C. poliogenys Brooks, C. sanfordi Stresemann, C. umbratilis (Strickland), C. olivaceus Hume, C. ruficauda (Sharpe)]. Except for C. poliogenys and C. sanfordi, all the species of Niltavinae that lack blue colouration were formerly placed in other genera (Ficedula, 'Rhinomyias'), underscoring the difficulty of defining higher taxa of Muscicapidae on the basis of morphology. Nevertheless, compared to the various chat genera, tarsi and toes are much smaller in Niltavinae. Bill width of most species of Niltavinae (including Anthipes monileger) is greater than in Ficedula. Most have proportionately longer tails, larger size, and simpler plumage patterns than in most dichromatic Ficedula. Dichromatic males usually have shining blue patches on forehead, carpal area, and/or elsewhere, but usually lack white supercilia, wing and/or tail patches which are common among Ficedula. Underparts in Niltavinae are usually rufous, bluish, or blackish on breast, and whitish on lower underparts. 
Included taxa: In addition to the type genus, Niltavinae includes all species of Anthipes Blyth, 1847, Cyornis Blyth, 1843, Cyanoptila Blyth, 1847 and Eumyias Cabanis, 1850 (sensu Sangster et al. 2010).

\section{Acknowledgements}

We thank Edward C. Dickinson, Sven O. Kullander, Jiří Mlíkovský, Pamela C. Rasmussen and an anonymous referee for their advice and comments on the manuscript.

\section{Literature cited}

Blyth, E. (1843) Mr. Blyth's monthly report for December meeting, 1842, with addenda subsequently appended. Journal of the Asiatic Society of Bengal, 12, 925-1011.

Blyth, E. (1847) Notices and descriptions of various new or little known species of birds, Part II. Journal of the Asiatic Society of Bengal, 16, 118-157.

Cabanis, J. (1850) Museum Heineanum. Verzeichniss de ornithologischen Sammlung des Oberamtmann Ferdinand Heine, auf Gut St. Burchard vor Halberstadt, 1. Theil, de Singvögel. Frantz, Halberstadt, 233 pp. https://doi.org/10.5962/bhl.title.112135

Hodgson, B.H. (1837) Indication of a new genus of Insessores, tending to connect the Sylviadae and Muscicapidae. India Review, 1, $650-652$.

International Commission on Zoological Nomenclature. (1999) International Code of Zoological Nomenclature. Fourth Edition. The International Trust for Zoological Nomenclature, Padova, XXIX + 306 pp.

Sangster, G., Alström, P., Forsmark, E. \& Olsson, U. (2010) Multi-locus phylogenetic analysis of Old World chats and flycatchers reveals extensive paraphyly at family, subfamily and genus level (Aves: Muscicapidae). Molecular Phylogenetics and Evolution, $57,380-392$. https://doi.org/10.1016/j.ympev.2010.07.008

Zuccon, D. (2011) Taxonomic notes on some Muscicapidae. Bulletin of the British Ornithologists' Club, 131, $196-199$.

Zuccon, D. \& Ericson, P.G.P. (2010) A multi-gene phylogeny disentangles the chat-flycatcher complex (Aves: Muscicapidae). Zoologica Scripta, 39, 213-224.

https://doi.org/10.1111/j.1463-6409.2010.00423.x 